\title{
SOME REMARKS ABOUT THE SOILS OF THE ALLUVIAL PLAIN OF IRAQ, SOUTH OF BAGHDAD ${ }^{1}$ )
}

\author{
P. BURINGH and C. H. EDELMAN \\ International Training Centre for Aerial Survey, Delft \\ Section for Regional Soil Science, Geology and Mineralogy of the \\ Agricultural University, Wageningen
}

\section{INTRODUCTION}

In the beginning of 1954 we were given an opportunity to study the soils in the plains of Iraq, south of Baghdad. We were there to demonstrate how the soil survey, on scales of between 1 : 50,000 and 1 : 250,000, could be accelerated and improved by the application of the systematic photo-analysis (BurnNGH, 1953, 1954). The Iraqi authorities kindly put at our disposal a small collection of good aerial photographs on the scale of $1: 20,000$ of the region between the Mussayeb area near the Euphrates and the town of El Suwairah on the Tigris. The strip in question covered about 53,000 hectares $(130,000$ acres) and we were able to analyse and map some characteristic parts of this area, on a scale of $1: 50,000$, and to make a general survey of the whole territory. This reconnaissance occasioned the production of a general soil associations map on a scale of $1: 250,000$.

\section{The geNERAL SOIL ASSOCIATIONS MAP}

In order to explain what we have observed we shall start by discussing the general map (fig. 1).

The territory may be regarded as decidedly flat. Its elevation, over a distance of $50 \mathrm{~km}$, varies no more than a good $4 \mathrm{~m}$. As usual in alluvial plains, there are very important soil differences coupled with a microrelief, which is characteristic of the various land types.

Starting from the south-west, it appears that the sediments of the Euphrates show the characteristics of river levee soils and basin soils, with which our Dutch readers are familiar from the researches on the Netherlands river clay territory carried out by the Soil Survey Institute. The difference in height between the levees and the basins is considerable, and may amount to more than $2 \mathrm{~m}$. As a map on a scale of 1:50.000 was made of part of this area (fig. 2), we shall not go further into this matter.

North-east of the sub-recent Euphrates area is a desert zone, which forms part of the Greater Mussayeb irrigation scheme, now being executed. This desert zone has been intensively moulded by the wind; there are dunes of pseudo-sand (clay with a crumb size similar to that of sand) and practically the whole area is covered with a layer of varying thickness of the same pseudo-sand. Underneath this layer desert soils occur. This landscape is discussed below (see fig. 3).

In the next zone the landscape of a braided river (fig. 4) lies on the surface. For a few years past this has been irrigated. When crossing this area in a north-eastern direction, a widely curved levee of the Tigris is reached,

1) Received for publication July 1st, 1954. 
which has eroded the old landscape. The aerial photos suggest the presence of a real "point bar" of a meandering river. The erosion contact is not very conspicuous in the topography, but all the more so in the pattern of the soil differences. The Tigris has not only eroded the older river terrace from the side but has also broken through it, for the levees and basins of the Tigris also enclose a desert area with aeolian deposits and which rises slightly above the surroundings: it gives a photo image which recalls that of the covered desert soils in the centre of the studied area.

The Tigris with its enormous meanders shows clearly how small levees may be on the outside curves of a river. Quite close to the Tigris, basin soils are found which strongly recall those of the Euphrates. As small differences exist between the characteristics of the sediments of the two rivers, we have kept them separate in the legend. As a matter of fact they are also separate topographically. There is also a distinct difference in colour between the sediments of the Euphrates, which are pale to very pale brown and those of the Tigris which are more gray brown.

KNAPPEN and others (1952) attribute this colour difference to the presence of more basaltic rock in the parent material of the Tigris.

Summarizing, the territory south of Baghdad between the Euphrates and the Tigris shows three zones : a) that of the sub-recent levee and basin landscape of the Tigris, b) the same of the Euphrates and c) a zone of desert soils separating them, formed on old river sediments, of the type of the braided river. We had no opportunity of finding out whether these latter soils belong to one and the same system, or whether they include some parts with soils of different ages.

\section{DESCRIPTION OF THE SOILS OF THE LEVEE AND BASIN LANDSCAPE OF THE} EUPHRATES NEAR THE VILLAGE OF EL SABBAGHIYAH

The following conclusions were arrived at as a result of the systematic airphoto-analysis and subsequent field work of an area of about 2,000 hectares $(5,000$ acres) near El Sabbaghiyah (fig. 2). The natural landscape consisted of a levee separating two basins. The centuries old irrigation has greatly changed this scene. The silt brought down with the irrigation water has sedimented in the shape of silt levees which follow the tracks of irrigation canals. Consequently the basins, at least along the borders, were divided into a number of smaller basins, bounded by the silt levees. Along the larger canals the silt levees are broad and fairly high, along the smaller canals narrow and low. All these silt levees rest on the well-known basin clay; the soils in question therefore show a profile of an evenly mixed soil - the silt layer - resting on the heavy basin clay. The thickness of the silt cover may be $1 \mathrm{~m}$, but also $20 \mathrm{~cm}$ or less. These silt levee soils were divided into two groups : a deep one and a shallow one and it was possible to determine their extent. They form, as it were, the connecting link between the river levee soils and the basin soils. The river levee, of course, has also been raised considerably by the irrigation, but this was not visible from the soils themselves. In the shady orchards of date palms, which surround the village of El Sabbaghiyah, the layer of irrigation silt has mixed homogenously with the top-soil of the original river levee which, moreover, must have had practically the same granular composition. This homogenization wholly corresponds with what HoEksema 
SKETCH MAP OF BROAD SOIL ASSOCIATIONS BETWEen EL SABBAGHIYAH AND EL SUWAIRAH, IRAQ

1 tigris LeVEe solls, potentially well orained

2 TIGRIS BASIN SOILS, LOCALLY COVEREO BY IRRIGATION SILT RIDGES; POTENTIALLY POORLY DRAINEO

3 DESERT SOILS ON PLEISTOCENE BRAIDED RIVER SYSTEM, COMPLEX OF LIGHT BROWN GRAY, POTENTIALLY WELL EO SOILS AND GRAY TO GRAYISH BROWN, POTENTIALLY IMPERFECTLY DRAINED SOILS

4 DESERT SOILS ON PLEISTOCENE BRAIDED RIVER SYSTEM, COVERED BY LIGHT GRAY WIND DEPOSITS, POTENTIALY WELL TO MODEPATELY WELL DRAINED

5 EUPHRATES LEVEe aND gASIN SOILS, COVERED BY LIGHT gRAY WIND DEPOSITS WITH VARYING

6 euphrates levee solls, potentially well drained

7 EUPHRATES Basin SOILS, LOCALLY COVERED BY IRRIGATION SILT RIDGES,

00 olo settlement solls

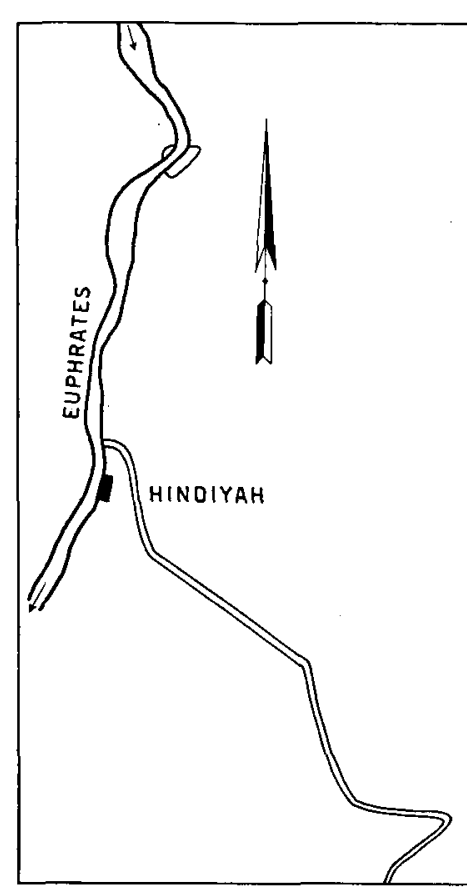
SOIL ASSOCIATIONS

approx. 1:250.000 


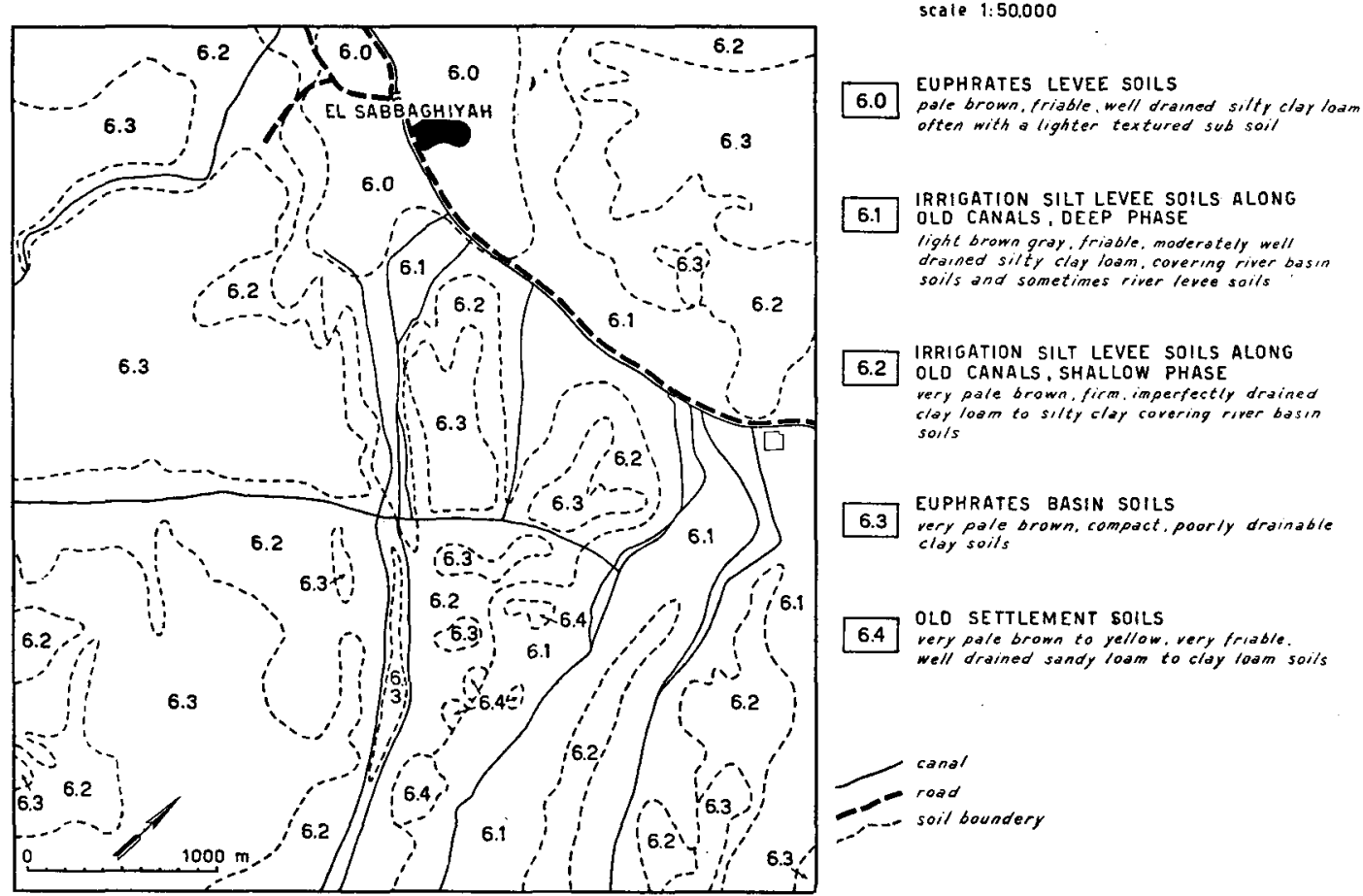

FIG. 2.

(1953) has found about it in the Netherlands. Outside the orchards, in the full blast of the sub-tropical sun, the biological homogenization has been much less and sometimes the silt layer can be clearly seen to rest on a subsoil of different texture.

The basin soils have, according to remains of a parcellation, previously been irrigated, but the drawback of the salination is such, that at present they are uncultivated. They serve as extensive grazing land. The superfluous irrigation water, at the end of the canals is allowed to flow calmly into the basins. Dependent upon circumstances, these basins are either white from the salt or flooded. The centre of the basin is characterized by a pattern of small gullies, sometimes straight, sometimes crooked and meandering, which gives the impression of a neglected irrigation system. At present they have partly been filled up with irrigation silt and are very saline.

In the Netherlands the soil scientists have explained many times the difference between the river levees and basins in the river clay territory. In Iraq, however, this difference is still greater. A more striking contrast than that between the fertile date palm orchards with their horticultural undersown crops and the barren saline unproductive basins nearby, is hardly conceivable.

It is interesting that the river levee soils have escaped salination after having been irrigated for many hundreds of years. This is due to the fact that there has always existed a kind of natural drainage towards the basins. The basins have received all the salts transported by the irrigation canals to 
the whole region. With other words : the basin soils have been sacrificed in favour of the levee soils.

In the area studied by us, the basins cover about half of the surface, the river and silt levees the other half.

It is not our intention to judge the possibilities of draining and desalinizing the basins; neither do we wish to express any views as regards the priority of such an enterprise above other development schemes, which Iraq has on its programme. But the region studied by us certainly represents an excellent example of what occurs if a river levee and basin landscape in a desert climate is irrigated without special drainage works.

The basin soils owe their inferior characteristics especially to the salination. They contain high percentages of lime and gypsum and they are less impermeable than certain Dutch basin soils. Nevertheless, it will be a very great undertaking to desalinize the basin soils in such a way that they can again regularly produce crops.

As mentioned before the interdependence of the soils in the river levee and basin landscape must not be lost sight off. This also applies to the present land use (orchard and horticulture, arable land and grazing land) as well as to the drainage and salt situation. This correlation immediately appears from the soil map. It is one of the great advantages of the soil map, over other maps, that it not only summarizes facts but moreover explains these facts. Therefore the soil map has also a great educational value.

\section{Description of the SOILS OF the DESERT AREA IN THE GREATER MUSSAIYeb IRRIGATION SCIEME}

As remarked before, the desert area east of the alluvial plain of the Euphrates is characterized by aeolian deposits (fig. 3), not only in the form of dunes, but also of a continuous cover. These aeolian deposits are quite recent. We visited this territory during a dust and sand storm, the worst for years, and we could observe that the whole top soil was in movement. It was also evident that the aeolian deposit is not tied to a certain subsoil and according to the wind direction may expand over all kinds of uncultivated land.

The sand which moves along the earth's surface is no sand in the real sense of the word. It is composed of crumbs of the size of sandgrains, but consists of flocculated clay, usually composed of a silty clay loam. Apparently they are flocculated by salt. The surface consists nearly everywhere of this pseudosand.

Underneath this recent cover desert soils occur, of which the compact Bhorizon is conspicuous because of its prismatic structure; it rests on a layer with lime concretions. This B-horizon also contains more clay parts than either subsoil and top soil. It is, therefore, believed that these desert soils in former times had the character of a solonetz, although this name cannot be applied nowadays, owing to the percentage of $\mathrm{NaCl}$ and gypsum. Be this as it may, there is no question of the soils in this desert zone being considered as alluvial soils, similar to the subrecent soils of the Euphrates as discussed under 2. Their subsoil is formed by river sediments; these have, at least in the east, the nature of a braided river, which must be of pleistocene age and which will be discussed in detail in the following paragraph.

The drift sand has been formed at the cost of the original A-horizon as well 

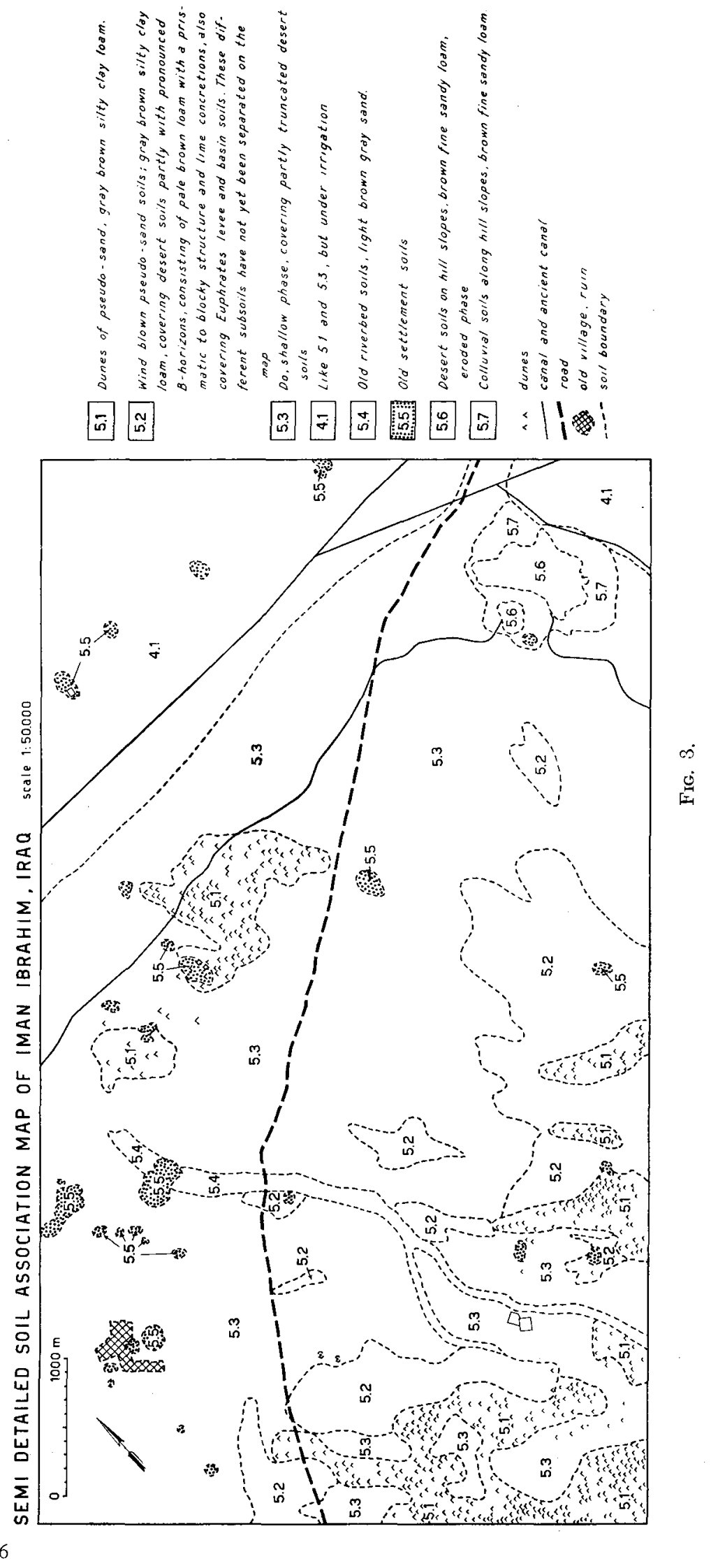
as of irrigation silt, emanating from ancient, long abandoned irrigations. There are places where the original B-horizon now lies at the surface and where, therefore, the A-horizon as well as the silt cover have disappeared as a result of wind erosion.

Our map does not provide a reply to the question where the desert soils in the west adjoin the alluvial soils of the Euphrates. This boundary lies concealed under the aeolian cover and could therefore not be determined by the airphoto-analysis. Owing to lack of time we were not able to map the boundary in question in the field; it has therefore been indicated on the general map (fig. 1) by a dotted line, while the legend of the semi-detailed map of fig. 3 does not take account of the deeper subsoil.

\section{SOME REMARKS REGARDING THE LANDSCAPE OF THE BRAIDED RIVER IN THE CENTRAL PART OF THE ALlUVIAL PLAIN}

As we had too little time to complete a small key map of this region, a sketchy discussion must suffice. The braided river consists of a tangle of innumerable small and large beds, which are excellently visible on the aerial photographs. In the field the smaller beds are found as shallow depressions with a width of about ten meters or less, in which the irrigation water stagnates and the crop fails. The larger beds are not so conspicuous, but they are all characterized by a dark coloured soil of a spongy structure, a kind of

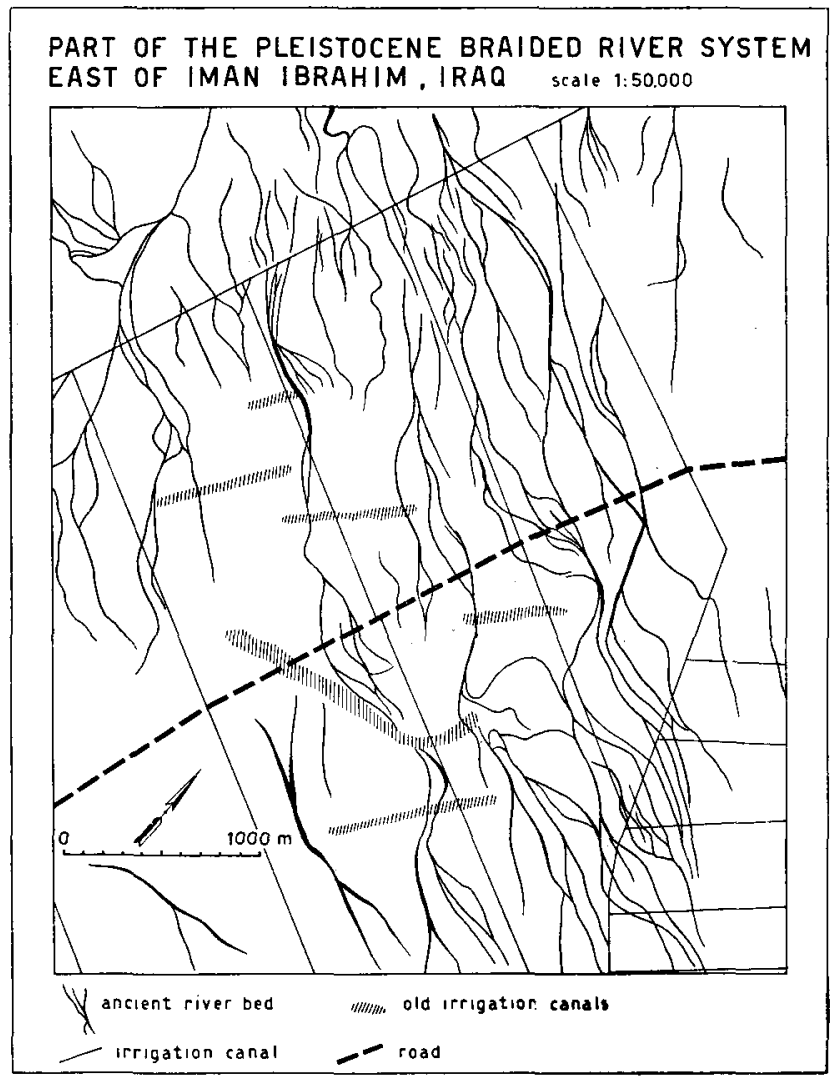

Fig. 4. 
marsh sediment in the middle of the light brown desert soils (fig. 4). These soils naturally require a detailed examination before they can be properly described, but their pattern is very striking and whoolly different from that of the basins and the levees of the sub-recent Euphrates and Tigris. This difference has great consequences for the irrigation and the salt danger. As explained under 2, the higher permeable soils in the levee-basin landscape have always had a certain drainage towards the lower impermeable soils, so that the higher grounds, notwithstanding a prolonged irrigation, have escaped the salt danger. In the much flatter landscape of the braided river all soils can be seen to salinize, notwithstanding a fair degree of permeability of the subsoil ; this is due to the lack of an external drainage. The salt trouble of the dark soils in the old river beds is indeed greater than in the brown desert soils, but this is only a question of sequence.

If we compare the composition of the sediments of this braided river with similar formations elsewhere, for instance with those of the fluviatile low terrace of the Rhine in the Netherlands (Pons \& Schelling, 1951 ; Bennema \& Pons, 1952), it is notable that coarse-grained sediments are lacking in the area described. There is no trace of gravel, while loose sand is only found locally and in small quantities. The drop of the ancient river locally has therefore been fairly small, though bigger than that of the present Tigris and Euphrates, which is about $10 \mathrm{~cm}$ per $\mathrm{km}$. For the low terrace of the Rhine the fall is about $26 \mathrm{~cm}$ per $\mathrm{km}$ whereas gravelly braided rivers have a still bigger fall, for instance $60 \mathrm{~cm}$ per $\mathrm{km}$. It will be interesting to follow the braided river of Iraq northwards and southwards. It may be expected that the braided river has sedimented coarser products to the north and shows a greater fall there. The difference in elevation with the recent sediments should become greater and greater towards the north. Towards the south the braided river - at a short distance from the spot studied - has to disappear underneath the young sediments.

Notwithstanding the fairly slight fall of the braided river, it clearly indicates a sea level which must be much lower than the present one. This is the reason why we have considered the sediments of the braided river as pleistocene. We cannot produce direct proofs for this assertion after such a superficial examination.

\section{The DWELLING HILLS AND OTHER TRACES OF ANCIENT HUMAN ACTIVITY}

The plain of Iraq has been inhabited so long that traces of human activity are legion. The strip which we have studied is situated not far from the ruines of Babylon. The irrigation system in which the village of El Sabbakhiyah is situated, is believed to have been constructed under Alexander the Great. (The territory reproduced in fig. 3 was all cultivated at that time). Much has been written about the antiquity of Mesopotamia and in principle it will be possible to date many of the old engineering works and dwelling places.

The airphoto-analysis may prove very useful in this respect. Such research is also important for the schemes, now under consideration in Iraq. It is generally assumed that the old irrigation areas have been abandoned due to the salination of the country. At present large sums are being invested in new irrigation works. The salt problem makes high demands on drainage (DE GRUYTER, 1953), which has so far found little or no application in Iraq. The study 
of the experience of previous generations may produce information which is of the greatest importance for the future.

\section{Final REMARKS}

The demonstration which we have given in Iraq of the latest methods of soil survey based on the systematic airphoto-analysis may be regarded as successful. Within a few days we were able to show some very important differences in the soil conditions in a territory previously unknown to us and produce the major soil boundaries on maps of different scales and intensities. Until recently this would have been impossible in such a short time.

We also wish to point out that the mapping of soil associations on a natural basis links up very well with the traditions of soil survey in the Netherlands. Many of the Dutch soil units, such as river levee soils, basin soils, creek ridge soils, marsh soils, new land- and old land soils, are nothing else than soil associations with a landscape basis (see EDELman, 1950, preface). This method of combining soil types may very well be considered as characteristic of the Dutch style in soil survey. The new technique, the systematic airphoto-analysis, makes it possible that large areas, of which so far no maps exist, are mapped systematically with a limited amount of field work five to ten times quicker than was hitherto possible.

If to this basis of the soil survey is added the historical and archeological evidence which is also characteristic of the Dutch method of working, it may be concluded that Iraq is a most attractive object for soil scientists of the Dutch school. With simple means they will be able to make maps of great economic and at the same time scientific value.

\section{REFERENCES}

Bennema, J. and L. J. Pons : Pleistocene outcrops, fluvial Low-Terrace and Eemian deposits in the western part of the river district. Boor en Spade, 5 (1952) 126-137. (Dutch with Eng. summ.).

Buringr, P.: The role of aerial photography when drafting schemes for underdeveloped countries. Netherl. Journ. Agr. Sc. 1 (1953) 251-255.

- - : The analysis and interpretation of aerial photographs in soil survey and landclassification. Netherl. Journ. Agr. Sc. 2 (1954) 16-26.

Edelman, C. H. : Soils of the Netherlands. Amsterdam, 1950.

Edelman, C. H. c.s. : A soil survey of the Bommelerwaard boven den Meidijk. 's-Gravenhage, 1950. (Dutch with Eng. summ.).

GruYter, P. DE : Drainage in Iraq. De Ingenieur, 65 (1953) B 1-17. (Dutch with Eng. summ.).

Hozksems, K. J.: The natural homogenization of the soil profile in the Netherlands. Boor en Spade, 6 (1953) 24-30. (Dutch with Eng. summ.).

Knappen, Tippetts, Abbetr \& Mc Carthy : Report on the development of the Tigris and Euphrates river systems. New York-Baghdad, 1952.

Pons, L. J. \& J. Schelling: The late-glacial deposits of the Rhine and the Meuse Geol. en Mijnbouw, 13 (1951) 293-297. (Dutch).

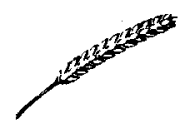

